\title{
Exposure to classroom sound pressure level among dance teachers in Porto Alegre (RS)
}

\author{
Cristiane Nehring ${ }^{1}$, Magda Aline Bauer ${ }^{2}$, Adriane Ribeiro Teixeira3 ${ }^{3}$. \\ 1) Student of Speech Therapy and Audiology. Scientific Initiation Scholarship BIC-UFRGS \\ 2) Masters in Communication Disorder. Speech therapist at the Federal University of Rio Grande do Sul. \\ 3) $\mathrm{PhD}$ in Biomedical Gerontology. Adjunct Professor of Audiology at the Federal University of Rio Grande do Sul \\ Institution: Federal University of Rio Grande do Sul (UFRGS) \\ Porto Alegre / RS - Brazil \\ Mailing address: Adriane Ribeiro Teixeira - Federal University of Rio Grande do Sul - Rua Ramiro Barcelos, 2600 - Institute of Psychology - UFRGS - Porto Alegre - \\ RS - Brazil - Zip code: 90035-003 - E-mail: adriane.teixeira@gmail.com \\ Article received in August 23, 2012. Article accepted in October 22, 2012.
}

\section{SUMMARY}

Introduction: Dance teachers are exposed to high sound intensities.

Aim: To verify the sound intensity of music used by dance teachers during classes.

Method: This was a transversal and prospective study. Dance teachers were evaluated with a sociodemographic questionnaire, and sound intensity level measurements were taken at the beginning, middle, and end of dance classes.

Results: The sample comprised 35 teachers (average age, 31.8 years). The duration of their career as dance teachers was $1-$ 37 years; they worked daily for approximately 1-10 h. Among the classes followed, there were 15 (42.85\%) classical ballet classes, 4 (11.42\%) tap dancing lessons, 5 (14.28\%) jazz dance classes, 2 (5.71) Arab dance lessons, 6 (17.14\%) street dance classes, and $3(8.57 \%)$ ballroom dancing lessons. The average values observed at the beginning, middle, and end of the classes were 80.91 $\mathrm{dB}$ (A), $83.22 \mathrm{~dB}$ (A), and 85.19 dB (A), respectively. The music played in the street dance classes exposed teachers to the highest sound intensity.

Conclusion: The average level of sound intensity of the dance classes in this study was either below or equal to the limit considered harmful for hearing health. Analysis of different class types showed that the sound densities of street, ballroom, and tap dance classes were above the recommended limits.

Keywords: sound; noise effects; noise, occupational; noise effects.

\section{INTRODUCTION}

Sound is part of people's lives and is present in many forms. In modern society, there are many unpleasant and undesirable sounds and these are called noise. The effect of noise on individuals depends on its characteristics (amplitude, frequency, and duration) as well as individual attitudes and relations to that noise.

The ability to recognize sounds allows humans to effectively detect relevant events, even in the absence of visual information (1). However, hearing loss is one of the most common occupational diseases in industrialized countries. In Brazil, noise-induced hearing loss is one of the main health problems facing workers, and researchers have stated that it is as one of the occupational diseases with the highest incidences (2).

For intensity, sound levels of 85-90 dB (A) may cause irreversible cell damage. The higher the noise level is, the greater the injury. The consequences for hearing are also directly proportional to exposure time; thus, the longer this exposure is, the more severe the changes to hearing are. In cases where there is noise in the workplace that is harmful to workers' hearing, hearing protection measures should be undertaken $(3,4)$.

When environmental noise is measured, different intensities and frequencies are captured. Nevertheless, there may be no association between frequency ranges with intense noise levels and the frequencies affected by hearing loss. There are, for example, cases in which noise intensity can be a major risk factor for hearing loss, regardless of the frequency band (5).

The Labor Ministry (1994) limits that are based on the standard of the American Conference of Governmental Industrial Hygienists: $16 \mathrm{~h}$ for exposure to $80 \mathrm{~dB}(\mathrm{~A}) ; 8 \mathrm{~h}$ for $85 \mathrm{~dB}(\mathrm{~A})$; $4 \mathrm{~h}$ for $90 \mathrm{~dB}$ (A); $2 \mathrm{~h}$ for $95 \mathrm{~dB}$ (A); $1 \mathrm{~h}$ for $100 \mathrm{~dB}$ (A); $30 \mathrm{~min}$ for $105 \mathrm{~dB}$ (A); and $7 \mathrm{~min}$ for up to 115 $\mathrm{dB}$ (A). Thus, maximum daily exposure is halved with every additional $5 \mathrm{~dB}$ (A) increase in the sound pressure level (SPL) (6).

In a study conducted in Florida, USA, researchers found that noise is a comprehensive and influential source of stress either due to the acute effects of noise or due to 
the influence of chronic exposure to high SPLs. In that study, the effects of noise during various tasks was tested and performance was measured; the type, intensity, and duration of the noise were all observed. The authors concluded that intermittent noise is more disturbing than continuous noise ( 7 ).

Studies on the exposure to high SPLs have generally been conducted on workers who are exposed to noises that are considered unpleasant (in the fields of civil construction, metallurgy, mechanical and the military, among others) $(5,8,9,10)$. However, noises that are considered pleasant, as in the case of music, can also cause significant damage to the inner ear (11).

Studies conducted in Brazil and abroad have investigated the different effects of high intensity music on the auditory system $(11,12,13)$. For professionals such as gymnasts and dance teachers, music is indispensable to work completion. Generally, such professionals are not submitted to audiometric tests when they are hired or dismissed, and do not undergo periodic evaluations of their hearing. Moreover, these professionals often ignore the effects of noise on the body, subjecting themselves to high sound intensities for long periods, without using individual protection equipment; this can cause significant damage to their hearing (14).

KRISHNAMURTI and GRANDJEAN (2003) investigated the association between exercise in a class environment and sound levels of moderate to severe intensity. They found that teachers used high SPLs in indoor cycling programs because students required them and felt more motivated if the music was louder (15). This finding was also reported by Deus et al. (16).

However, few studies have looked at exposure to high SPLs among dance professionals. Therefore, we decided to measure the sound intensity levels of their dance classes.

\section{MetHod}

The study comprised transversal delineation as well as observational and in-group comparison. We used convenience sampling in a non-probabilistic manner.

Initially, we contacted people running dance schools and presented our project. When there was approval for its realization, the people in charge of the schools signed an institutional consent form. After that, we contacted the teachers to explain the objectives of the research and to invite them to participate. Individuals who agreed to participate also signed an individual consent form.

The study sample comprised male and female dance teachers. There was no prior selection as to the dance style because many of the teachers had practiced various styles of dance when they were students; further, the classes covered more than 1 style.

The inclusion criteria were as follows: being an active dance teacher, being willing to participate in the study, and allowing a researcher to measure sound intensity in their dance classes.

After signing the individual consent form, participants completed a sociodemographic questionnaire specifically developed for this study This comprised questions about the individual's dance history (professional education, time as a performing dancer, time as a dance teacher, and styles performed). In addition, we asked directed questions that allowed for assessment of teachers' opinions on music intensity during classes. Furthermore, we were able to ask for details on how much information the dance teachers had received on the effects of high levels of sound pressure on the body.

A researcher then measured the normal sound intensity levels used by the study participants in their classes. The researcher attended the classes of all participants and recorded the sound intensity level used by the teacher in the classroom 3 times: 5 min after the start of the class, $30 \mathrm{~min}$ into the class, and $5 \mathrm{~min}$ before the end of the class. The 30-min mark was selected because it corresponded to half of the class duration. When class durations were shorter or longer, the second measurement was made at a time point equivalent to half of the class duration. The measurement time was approximately $1 \mathrm{~min}$, as in previous studies (17).

For the above measurements, we used a sound pressure meter (DL-4020 ICEL Manaus, Manaus, Brazil). The teacher's usual location in the classroom during classes was selected for taking measurements; this was mostly at the front of the class or in the middle of the room. We measured the maximum intensity peak used and the scale (A). The meter was adjusted to the weighting curve "A" and the slow time constant (i.e., slow RMS sound pressure in $1 \mathrm{~s}$ ). With these settings, the meter picks up the sound in a similar manner to the human ear. This scale shows correlation with the subjective tests. and, this is the compensation circuit used for measuringement of continuous noise (18).

When the measurements were completed, teachers were informed about the values and advised about the effects 
of exposure to high SPLs. Information designed to facilitate retention of this information was prepared and distributed.

This project was approved by the Research and Ethics Committee and Research Institute of Psychology at the Federal University of Rio Grande do Sul (No 2011009).

The data obtained were analyzed using quantitative, descriptive statistics. We calculated the absolute and relative frequencies and average SPLs that the teachers were exposed to.

\section{RESULTS}

The sample comprised 35 individuals including 11 (31.42\%) men and 24 (68.57\%) women. The average age of participants was 31.8 years (range, $18-55$ years). The average time spent working as a dance teacher was 12.81 years (range, $1-37$ years), and the average daily teaching load was $4.48 \mathrm{~h}$ (range, $1-10 \mathrm{~h}$ ). Details on teacher training are presented in Table 1.

For self-reported intensity of the music used in classes, questionnaire results revealed that 1 teacher $(2.85 \%)$ classified this intensity as soft, 19 teachers (54.28) described this as average, and 15 (42.85\%) said it was strong. When asked about the reasons for using loud music, 14 teachers (40\%) reported that they believed it improved student performance.

In addition, 24 teachers (68.57\%) said they never received information about the effects of high pressure sound levels on the body.

Measurements of sound intensity levels were taken in 15 classical ballet classes (42.85\%), 4 tap dance classes (11.42\%), 5 jazz dance classes (14.28\%), 2 Arab dance classes (5.71\%), 6 street dance classes (17.14\%), and 3 ballroom dance classes (8.57\%).

The minimum value observed during the initial phase of the classes was $65 \mathrm{~dB}$ (A) and the maximum value was $95 \mathrm{~dB}$ (A). The average for this first time point was $80.91 \mathrm{~dB}$ (A). For the measurements taken half-way through the class, the minimum and maximum values were $70 \mathrm{~dB}$ (A) and $95 \mathrm{~dB}(\mathrm{~A})$, respectively, with the average being $83.22 \mathrm{~dB}(\mathrm{~A})$. In the final period of the classes, the minimum value was $72 \mathrm{~dB}$ (A) and the maximum value was $98 \mathrm{~dB}$ (A); the average at this final time point was $85.19 \mathrm{~dB}$ (A). Measurements of SPLs at different time points during the classes are presented in Table 2 .

After measuring the average intensity level of music found in different types of dance classes at different time points, we found that the street dance classes had the
Table I. Training undergone by participating dance teachers.

\begin{tabular}{lcr}
\hline Education & $\mathrm{n}$ & $\%$ \\
\hline Dance school & 2 & 5.71 \\
Physical education school & 9 & 25.71 \\
Technological course in dance & 2 & 5.71 \\
Classical ballettraining & 10 & 28.57 \\
Masters course with emphasis on dance & $\mathrm{I}$ & 2.85 \\
Dance school and classical ballettraining & 2 & 5.71 \\
Physical educationschooland classical ballettraining & 5 & 14.28 \\
Technologistindance and classical ballettraining & $\mathrm{I}$ & 2.85 \\
Dance school and physical educationschool & 2 & 5.71 \\
Other & $\mathrm{I}$ & 2.85 \\
\hline Total & 35 & 100 \\
\hline
\end{tabular}

Table 2. Distribution of sound pressure levels during dance classes.

\begin{tabular}{|c|c|c|c|c|c|c|}
\hline & \multicolumn{2}{|c|}{$\begin{array}{l}\text { Beginning } \\
\text { of class }\end{array}$} & \multicolumn{2}{|c|}{$\begin{array}{l}\text { Middle } \\
\text { of class }\end{array}$} & \multicolumn{2}{|c|}{$\begin{array}{l}\text { End } \\
\text { of class }\end{array}$} \\
\hline & $\mathrm{n}$ & $\%$ & $n$ & $\%$ & $n$ & $\%$ \\
\hline$\leq 80 \mathrm{~dB}(\mathrm{~A})$ & 19 & 54.3 & 13 & 37.1 & 6 & 17.1 \\
\hline $80.1-85 \mathrm{~dB}(\mathrm{~A})$ & 3 & 8.6 & 8 & 22.9 & 17 & 48.6 \\
\hline $85.1-90 \mathrm{~dB}(\mathrm{~A})$ & 7 & 20 & 7 & 20 & 6 & 17.1 \\
\hline $90.1-95 \mathrm{~dB}(\mathrm{~A})$ & 6 & 17.1 & 7 & 20 & 5 & 14.3 \\
\hline$>95 \mathrm{~dB}(\mathrm{~A})$ & 0 & 0 & 0 & 0 & । & 2.9 \\
\hline
\end{tabular}

Table 3. Average intensitylevels at different time points during classes by the dance style

\begin{tabular}{lccc}
\hline & $\begin{array}{c}\text { Beginning } \\
\text { of class dB (A) }\end{array}$ & $\begin{array}{c}\text { Middle } \\
\text { of class dB (A) }\end{array}$ & $\begin{array}{c}\text { End } \\
\text { of class dB (A) }\end{array}$ \\
\hline Classical ballet & 75.66 & 77.6 & 81.73 \\
Jazz & 75 & 83.4 & 86.25 \\
Tapdance & 86.25 & 91.5 & 91.25 \\
Arabdance & 78.54 & 83 & 77 \\
Streetdance & 89.50 & 89.66 & 91.33 \\
Ballroomdance & 84 & 87.33 & 84.66 \\
\hline
\end{tabular}

highest levels of sound intensity. Classical ballet classes had the lowest sound intensity level (Table 3).

\section{DISCUSSION}

Dance teachers are continually exposed to high SPLs and may suffer hearing damage due to this exposure. Furthermore, dance teachers do not generally undergo periodic hearing checkups or control the sound intensity during their classes.

It is estimated that $25 \%$ of the population is exposed to occupational noise and has some degree of hearing 
impairment (3). Dance teachers may be part of this group although studies on this population are few.

Our study sample included mainly female participants; this reflects the reality of most dance schools and dance-related fields where female dance teachers and students prevail. The gender issue is noteworthy and men are rarely found, especially in styles such as classical ballet, belly dancing, and modern dance. One relevant factor is that dance performers are not afforded the same prestige as performers of other artistic activities such as theater and cinema (19). Thus, many men take dance classes as an ancillary complement to their acting in other areas, but do not dedicate themselves to it professionally. This data was expected and confirms the results obtained within in previous literature (19).

Our study sample was also young and the elderly were not present. The average age of the study subjects was 31.5 years, and 9 professionals were aged over 40 years. Although this is a small number, the presence of middle-aged dancers working on a daily basis as teachers seems to shatter the myth that people need to abandon the practice of dancing as they get older. Thus, we disagree with the findings of previous studies, which indicate that, even today, it is rare to find cases of older dancers working professionally (19).

In terms of the training undertaken by teachers (Table 1), we found that many of our study subjects (51.42\%) had trained in classical ballet at dance schools although few had completed college degrees in the same field. This can be attributed to the lack of higher education courses in dance in Brazil. Specifically, in Rio Grande do Sul, the first such course was only offered in 2002 at a state university. In addition, the state capital only offered its first graduate degree course in 2009 and the first batch of students have not graduated thus far $(20,21)$. Thus, it is believed that the training profile of teachers will change in the long run, with graduate students being absorbed into the workplace.

In the present study, the average daily teaching load was $4.48 \mathrm{~h}$, but many teachers are exposed to high SPLs for longer periods of time; this is because they reported using high intensity music outside of the classroom in the questionnaire. Continuous exposure to high SPLs can lead to other adverse health effects besides hearing loss, such as changes related to sleep, breathing, anxiety, cardiovascular function, the immune system, and fatigue (22). Therefore, it is important that teachers are aware of the auditory and extra-auditory effects due to noise.

Thus, we developed an extension project comprising printed information that aimed to prevent hearing loss induced by high SPLs.

Tables 2 and 3 show that the SPLs measured in some of the classrooms were above the limits of acoustic comfort for indoor environments; further, they were above the limit of $85 \mathrm{~dB}$ (A). Analysis by dance style revealed that street, tap, and ballroom dance classes had sound intensities above $85 \mathrm{~dB}$ (A). It should be noted that in tap dance, along with the effects of music, the effects of metal hitting against floor was also registered; this must have caused an increase in sound intensity in the class rooms studied. Hence, teachers were informed about the importance of lowering music levels. Taking into account that high SPLs were also used to improve class performance, we recommended that teachers look at possible new ways to motivate students.

Our data are consistent with the findings of research from health clubs registered in the city of Florianopolis (SC), in which most of the SPLs measured were above the recommended limits. That study found that $86 \%$ of academies had average noise values above the legal limit (16).

In a similar study conducted in the city of Curitiba (PR), researchers found that SPLs ranged from $73.9 \mathrm{~dB}$ (A) to $94.2 \mathrm{~dB}$ (A) and that the most common complaints among teachers were tinnitus, muffled hearing, and difficulties in concentration (23). High SPLs during the lessons can, therefore, become a serious occupational health problem for workers. Thus, we wish to highlight once again that dance teachers do not undergo periodic hearing tests and do not use individual protection equipment as workers in other fields (e.g., metallurgy, mechanics, and wood sawing). Furthermore, dance teachers' workplaces are not submitted to audio checkups, in which SPLs are measured.

Thus, it is believed that dance teachers should be targeted for speech therapy. As is the case for all other workers who are exposed to noise, they should be well informed about the risks to their hearing (24). The role of speech therapists in the area of worker's health must not be restricted to conducting audiometric evaluations. Speech therapists must also explain hearing loss issues to help prevent excessive noise exposure (19).

Hearing loss resulting from high intensity music may be evolving into a significant public health problem because increasing numbers of adolescents and young adults have symptoms such as neurosensory hearing loss, tinnitus, and hyperacusis $(25,26)$.

Previous studies on SPLs measured in dance classes were limited in scope; future studies should look at sound 
intensity as well as hearing loss. Dance teachers are usually exposed to music early in life, because training in many styles including, for example, classical ballet, begins in early childhood. Individuals frequently go on to practice several styles, and the teachers in our study sample reported that they used music at high intensity to motivate students to improve their performance. Thus, exposure to noise may begin very early, and hearing loss and other symptoms might affect individuals in childhood or adolescence.

In summary, professionals exposed to high intensity music at the work place should be informed about the importance of using music at appropriate SPLs. These teachers should also be helped to establish strategies for their individual protection. In addition, dance shools should have classrooms with better acoustic properties including the use of noise-absorbing wall, floor, and ceiling materials. Well-designed speakers should be used and placed in the best position $(17,27)$.

\section{CONCLUSION}

The data obtained in this study shows that the average SPLs used by dance teachers in their classes were below or equal to the recommended limits. However, analysis of intensities by the dance style revealed that noise levels in several tap and street dance classes were above $85 \mathrm{~dB}(\mathrm{~A})$.

\section{REFERENCES}

1. Staeren NI, Renvall H, De Martino F, Goebel R, Formisano E. Sound Categories Are Represented as Distributed Patterns in the Human Auditory Cortex. Current Biology. 2009; 19(6):498-50.

2. Gabas G. Escute bem e proteja-se. Rev Proteção. 2007;181:54-61.

3. Brasil. Ministério da Saúde. Secretaria de Atenção à Saúde. Departamento de Ações Programáticas Estratégicas Perda auditiva induzida por ruído (PAIR)/Ministério da Saúde, Secretaria de Atenção à Saúde, Departamento de Ações Programáticas Estratégicas. - Brasília: Editora do Ministério da Saúde; 2006.

4. Mehrparvar AH, Mirmohammadi SJ, Ghoreyshi A, Mollasadeghi A, Loukzadeh Z. High-frequency audiometry: A means for early diagnosis of noise-induced hearing loss. Noise Health. 2011;13:402-406.

5. Boger ME, Barbosa-Branco A, Ottoni AC. A influência do espectro de ruído na prevalência de Perda Auditiva Induzida por Ruído em trabalhadores. Braz J Otorhinolaryngol. 2009;75(3):328-334.

6. Brasil. Ministério do Trabalho-Manuais de LegislaçãoNormas Regulamentadora (NR) do Ministério do Trabalho - Lei n 6.514 de 22 de dezembro de 1977, Portaria 3.214 de 08 de junho de 1978, Brasil, São Paulo: Atlas, 1994.

7. Szalma JL, Hancock PA. Noise Effects on Human Performance: A Meta-Analytic Synthesis. Psychological Bulletin. 2011;137(4):682-707.

8. Heupa AB; Gonçalves CGO; Coifman H. Efeitos do ruído de impacto na audição de militares. BrazJ Otorhinolaryngol. 2011;77(6):747-753.

9. Guerra MR, Lourenco PMC, Bustamante-Teixeir MT, Alves MJM. Prevalência de perda auditiva induzida por ruído em empresa metalúrgica. Rev.SaúdePública. 2005;39(2):238-244.

10. Farias VHV, Buriti AKL, Rosa MRD. Ocorrência de perda auditiva induzida pelo ruído em carpinteiros. Rev CEFAC. 2012;14(3):413-422.

11. Maia JRF, Russo, ICP. Estudo da audição de músicos de rock and roll. Pró-Fono. 2008;20(1):49-54.

12. Andrade AIA, Russo ICP, Lima MLLT, Oliveira LCS. Avaliação auditiva em músicos de frevo e maracatu. Rev Bras Otorrinolaringol. 2002;68(5):714-720.

13. Ebare MN, Omuemu VO, Isah EC. Assessment of noise levels generated by music shops in an urban city in Nigeria. Public Health. 2011;125:660-4.

14. Gonçalves CGO, Lacerda ABM, Zocoli AMF, Oliva FC, Almeida SB, Iantas MR. Percepção e o impacto da música na audição de integrantes de banda militar. Rev. Soc Bras Fonoaudiol. 2009;14(4):515-20.

15. Krishnamurti S, Grandjean PW. Effects of simultaneous exercise and loud music on hearing acuity and auditory function. J Strength Cond. Res. 2003;17(2):307-13.

16. Deus MJ, Duarte MFS. Nível de Pressão Sonora em Academias. Revista Brasileira de Atividade Física e Saúde. 1997;2(2):05-16.

17. Palma A, Mattos UAO, Oliveira GEMC. Nível de ruído no ambiente de trabalho do professor de educação física em aulas de ciclismo indoor. Rev. Saúde Pública 2009;43(2):34551.

18. Sampaio Neto RA, Mesquita FOS, Paiva Junior MDS, Ramos FF, Andrades FMD, Correia MAV. Ruídos na unidade 
de terapia intensiva: quantificação e percepção dos profissionais de saúde. Rev Bras Ter Intensiva. 2010;22(4):369-74.

19. Brandao MD. Engajamento na dança: uma profissão tratada como juvenil. Rev Bras Ci Soc. 2012;27(78):183-6.

20. Samelli AG, Fiorini AC. Saúde Coletiva e Saúde do Trabalhador: Prevenção de Perdas Auditivas. In: Bevilacqua MC, Martinez MAN, Balen AS, Pupo AC, Reis ACMB, Frota S. Tratado de Audiologia. Livraria Santos Editora Ltda; 2011. p. $455-74$.

21. Site do Curso de Dança da Universidade Estadual do Rio Grande do Sul <http://www.uergs.edu.br/ index.php?action $=$ cursosLocaisDesc.php\&cod $=7>$. Acesso em 10 de agosto de 2012.

22. Site do Curso de Dança da Universidade Federal do Rio Grande do Sul. <http://www1.ufrgs.br/graduacao/ xinformacoesacademicas/curriculo.php?CodHabilitacao= 151\&CodCurriculo=1\&sem $=2009022>$. Acesso em 10 de agosto de 2012.
23. Vogel I, Brug J, Hosli, EJ, van der Ploeg CPB, Raat H. MP3 Players and Hearing Loss: Adolescents' Perceptions of Loud Music and Hearing Conservation. The Journal of Pediatrics. 2008;152(3):400-4.e1.

24. Vogel I, Verschuure H,van der Ploeg CPB,Brug J, Raat H. Adolescents and MP3 Players: Too Many Risks, Too Few Precautions. The Journal of Pediatrics. 2009;123(6):E9538.

25. Lacerda ABM, Morata TC, Fiorini AC. Características dos níveis de pressão sonora em academias de ginástica e queixas apresentadas por seus professores. Rev Bras Otorrinolaringol. 2001;67(5):656-59.

26. Bramatti L, Morata TC, Marques JM. Ações educativas em Programa de Conservação Auditiva. Rev CEFAC. 2008;10(3):398-408.

27. Andrade IF, De Souza AS, Frota SMMC. Estudo das emissões otoacústicas-produto de distorção durante a prática esportiva associada à exposição à música.Revista CEFAC. 2009;11(4):644-61. 